Afrika Focus, Vol. 12, Nr. 1-2-3, 1996, pp.3-25

\title{
The Rational Rebel: How Rational, How Rebellious? Some African Examples
}

\section{Rob BUIJTENHUIJS}

Afrika-Studiecentrum

P.O Box 9555

2300 RB Leiden, The Netherlands

\section{SUMMARY}

My aim in this article is to evaluate some general statements on civil violence, and more particularly on the purposefulness of collective action and on the alleged rationality that moves social actors launching rebellion. With the use of African examples, examples that are too seldom taken into account in theoretical explanations of violent conflict ${ }^{l}$, it is shown that rationality in collective action can certainly not be dismissed out of hand, but that some caveats have to be entered into the argument: some African rebels, although acting rationaly, base themselves on completely erroneous information, while in other cases social actors consciously opt for life or a career as a rebel, but out of motives that anything but "revolutionary".

KEY WORDS: Civil violence, Rational choice theory, Africa South of the Sahara.

1. Cf. T.R. Gurr, "Theories of Political Violence and Revolution in the Third World", in F.M. Deng and I.W. Zartman (eds), "Conflict Resolution in Africa", The Brookings Institution, Washington D.C., 1991, p. 154. 
The authors I will discuss are those who claim that revolutions, rebellions, and lesser forms of coercive civillian conflict are best understood as "a mere continuation of politics by other means", i.e. that they "arise from ongoing contests for resources, influence, and hegemony previously managed within existing diplomatic channels". ${ }^{2}$ This implies that rebels are rational people who use force in political or economic conflicts "not because they have not carefully considered all possible alternatives, but because they have". ${ }^{3}$ In the words of R. Aya, revolutions and rebellions "entail calculated risks and tests of strength: the contenders gauge each other's intentions and capabilities, and fight if they think they can get their way no other way, and get away with it". ${ }^{4}$ Or, as schematized by $\mathrm{Ch}$. Tilly:

"1. Collective action costs something.

2. All contenders count costs.

3. Collective action brings benefits, in the form of collective goods.

4. Both costs and benefits are uncertain because (a) contenders have imperfect information about the current state of the polity; (b) all parties engage in strategic interaction". 5

Tilly's point 4 already indicates that several authors working with these premises do enter some caveats into their hypotheses, in Tilly's case based on the possibility of imperfect information and the occurrence of strategic interaction with other parties. Another warning is voiced by Aya, when he says that "rational-choice theory explains sane people's premeditated social actions, not the behaviour of infants, idiots, psychopats, and people who are senile, hallucinated, panicked or brain-damaged". ${ }^{6}$ Another point is made by F. Schiphorst who underlines that it is not only the information prospective rebels have about their situation that counts, but also their (subjective) perception of their social surroundings.

2. R. Aya, "Theories of Revolution Reconsidered: Contrasting Models of Collective Violence", Theory and Society, 8, 1979, p. 68.

3. J.M. Paige, "Agrarian Revolution: Social Movements and Export Agriculture in the Underdeveloped World", The Free Press, New York, 1975, p. XI.

4. R. Aya, "Rethinking Revolutions and Collective Violence: Studies on Concept, Theory and Method", Het Spinhuis, Amsterdam, 1990, p. 52.

5. Ch. Tilly, quoted in J.B. Rule, "Theories of Civil Violence", University of California Press, Berkeley-Los Angeles-London, 1988, p. 179.

6. R. Aya, "Rethinking Revolutions", p. 104.

7. F. Schiphorst, "Macht en onvermogen: Een studie van de relatie tussen staat en boeren op het VEA-irrigatie project, Ghana", Uitgave 20, Afdeling Culturele Antropologie, Antropologisch-Sociologisch Centrum, Universiteit van Amsterdam, 1983, p. 68. 
Although, when reading the works of the "rational rebel" proponents, I sometimes cannot help imagining some poor peasant sitting in his hut concentrating like a master chess-player, his wife whispering: "Hush children, quiet, father ponders over revolution", I basically agree with this way of thinking, especially when caveats such as those mentioned above are kept in mind. It is therefore not my intention, by using African examples, to completely dismiss theories stressing rationality in collective action and to try to revive the ideas of those whom J.B. Rule labels the "irrationalists". ${ }^{8}$ It is rather my purpose, while remaining within the realm of the rationalists' hypotheses, to emphasize the caveats that have to be entered into the argument, in order to make these theories plausible. First of all, I will turn to Tilly's point concerning rebels having "imperfect" information: some of my African examples do indead demonstrate that this is a serious understatement, because quite a few rebels act on the basis of not only imperfect, but completely erroneous information. Then I will turn to examples staging social actors who consciously opt for life or a "career" as a rebel, but whose motives are anything but "revolutionary", or in a more nuanced version, whose motives are a mixture of revolutionary intentions and more pedestrian, selfish interests.

\section{How rational?}

\section{Erroneous information}

Here I will consider the case of "rational" people who consciously decide to embark on the path of insurgency, but whose decisions are based on erroneous information and incorrect hypotheses. Let me first give an example of what Tilly rightly would term "imperfect information", an example that does not belong to the realm of rebellion, but to the related field of warfare. When the Allied Forces launched the military offensive against the Germans that culminated in the battle of Arnhem in September 1944, they certainly based themselves on rational calculations. Yet, the action failed markedly, one of the reasons being that the allied intelligence services had overlooked the presence, near the proposed battlefield, of a German pantzer-division recently transferred to the East of the Netherlands.

8. Cf. J.B. Rule, "Rationality and Non-Rationality in Militant Collective Action", Sociological Theory, 7 (2), Fall 1989. 
This case does not falsify the rationalists' hypotheses, and neither do the following cases of African insurgents acting, in these examples, on the basis of a too optimistic evaluation of the international environment that would bear on their endeavour. When the Union des Populations du Cameroun activists, under the leadership of Ruben Um Nyobé launched their rebellion against the French colonial authorities in May 1955, (or, better, threatened to revolt, eliciting a French pre-emptive move against the would-be rebels), they were acting on the basis of what $G$. Chaffard calls a "calcul chimérique"9. Cameroun being a United Nations' trusteeship territory, not just an "ordinary" colony, Um Nyobé's idea was that creating a "revolutionary situation" would be sufficient to entice the UN into immediate action in order to put an end to French oppression and to force the colonial authorities to hand over power to the "rightful" representatives of popular aspirations, i.e. Um Nyobé and his lieutenants. Unfortunately for the UPC, the UN did nothing of the kind, and the French were allowed to ruthlessly crush the incipient rebellion, without any foreign intervention taking place. ${ }^{10}$

In the same vein, the leaders of the Uniao das Populaçoes de Angola (UPA) overestimated UN influence when launching a revolt in Northern Angola in February 1961. Although the UN had indeed agreed, in November 1960, to take up the question of independence for the Portuguese colonies, which encouraged UPA leaders in their belief that they might expect Western, and more particularly US support in their efforts to oust the Portuguese, this expectation "proved disastrously exaggerated". ${ }^{11}$ J.M. Paige ${ }^{12}$ mentions another disastrous exaggeration to which the Northern Angolan nationalists fell victim: the precipitous exit of the Belgians from the Congo in the course of 1960 made them think that the Portuguese, too, would rapidly yield to the pressures of guerilla war, an estimation based on an incorrect evaluation of Lusitanian stubbornness and last-ditch mentality.

In these cases we are still within the limits of Tilly's "imperfect information", although the UPA's miscalculation of Portuguese reactions already goes a long

9. G. Chaffard, "Les carnets secrets de la décolonisation", Tome 2, Calman-Lévy, Paris, 1967, p. 348.

10. Although $R$. Joseph later claimed that Um Nyobé relied less heavily on UN intervention than is alleged by Chaffard, it is still beyond doubt that Cameroon's status as a trusteeship territory did enter into Um's calculations. Cf. R.A. Joseph, "Radical Nationalism in Cameroun: Social Origins of the U.P.C. Rebellion", Oxford University Press, Oxford, 1977, p. 192.

11. J.M. Paige, op. cit., p. 261.

12. Ibid., p. 261. 
way. But there are more impressive examples of rebels acting on the basis of incorrect data. The 1947 Malagasy insurgents are a case in point. J. Tronchon has the following to say on their lost revolt:

"La nouvelle se propage (en 1945) d'une France libérée par les Américains. Auréolés du prestige des libérateurs, ces derniers apparaissent aussitôt comme des alliés de choix (...). C'est sur la foi profondément ancrée que leur mouvement (..) recevra l'appui de certaines nations, et en particulier des Etats Unis, que les insurgés passent à l'attaque (...). Ce mythe de l'aide étrangère (...) fut déterminant dans la préparation, le déclenchement et le déroulement de l'insurrection". ${ }^{13}$

Tronchon's assertion is confirmed by Dana Robert, one of the military leaders of the Malagasy rebellion who put down his memories in writing after the war. ${ }^{14}$ So deeply anchored were the rebels' beliefs in foreign intervention that, on some occasions during the first days of the revolt, they mistook French soldiers for the expected American allies and were taken prisoner without resisting. ${ }^{15}$ It should be emphasized here that the Malagasy insurgents had no contact with any American before the rebellion, and that no promises of support were ever made by any outsider. The expected help existed only in their imagination. ${ }^{16}$

At other times, the outside support expected by African rebels was not related to Americans, but to prestigious political leaders of neighbouring countries. This was, for example, the case with the grass-roots rebels in Northern Angola who, during the first months of 1961, firmly believed that Patrice Lumumba, having

13. J. Tronchon, "L'insurrection malgache de 1947: Essai d'interprétation historique", François Maspero, Paris, 1974, pp. 133-134.

14. Cf. F. Fanony and N. Gueunier, "Deux documents sur l'insurrection malgache de 1947", Etudes Océan Indien, 3, 1983, p. 142.

15. J. Tronchon, op. cit., p. 133 and pp. 269-271.

16. The theme of Americans, and more specifically Black Americans, coming to the rescue of African rebels is recurrent in the literature on African civil violence. Already in the 1920's, Kimbanguist preachers were reported to have declared that the American Negro would come and deliver his Congo brother from white oppression (cf. Th. Hodgkin, "Nationalism in Colonial Africa", Frederick Muller Ltd., London, 1956, p. 108). Again, in 1921, an Ethiopian sect resisted removal from a "squatter" settlement near Queenstown, South Africa, in the belief that American Blacks would come to their aid in airplaines (Cf. W. Beinard and C. Bundy, "State Intervention and Rural Resistance: The Transkei, 1900-1965", in: M.A. Klein (ed.), "Peasants in Africa: Historical and Contemporary Perspectives", Sage Publications, Beverly Hill-London, 1980, p. 290). 
established the independence of the ex-Belgian Congo, would now extend his action to Angola and help his brothers at the other side of the border. ${ }^{17}$ Note that Lumumba had already been murdered when the Angolan insurgents vainly invoked his name, and that, here again, his supposed sympathy for the rebels' cause existed only in the imagination of its would-be beneficiaries.

In other cases, African rebels were heavily over-expectant concerning the support they would be able to obtain from their own political leaders. The Northern Angolan grass-roots fighters are again a case in point: several authors have reported that they were convinced, at least during the first months of the insurgency, that Holden Roberto, the main UPA leader, would come to their rescue by sending planes full of arms and carrying military leaders. ${ }^{18}$ The same rumours were current in Madagascar, in 1947, when the rebels thought that the French airplaines flying over the areas in revolt were transporting the nationalist leaders who represented Madagascar in the French National Assembly (in reality, these parlementarians had been arrested by the French at the beginning of the insurrection) ${ }^{19}$ In both these cases, the rebels' mistaken expectations had tragic consequences; indeed it happened more than once that enthusiastic insurgents, waving to enemy planes they took for their leaders' aircraft instead of hiding, were mercilessly gunned down by the French, respectively the Portuguese air-crews. Hundreds of rebels lost their lives in this way, especially in Angola. ${ }^{20}$

\section{Incorrect hypotheses}

The foregoing examples demonstrate, in my opinion, that Tilly is too cautious when he concedes that rebels can sometimes act on the basis of imperfect information. In the cases I have quoted, their information was frankly erroneous and did not match reality at all. Quite similar situations obtain when prospective insurgents wage war and think they can get away with it, in the firmly rooted belief that they are invincible because of magical devices. The history of African

17. R. Davezies, Les Angolais, Editions de Minuit, Paris, 1965, p. 50; R. Pélissier, "La colonie du minotaure. Nationalismes et révoltes en Angola" (1926-1961), Editions Pélissier, Orgeval, 1978, p. 559.

18. R. Davezies, op. cit., p. 33 and pp. 76-77.

19. J. Tronchon, op. cit., p. 83.

20. R. Pélissier, op. cit., p. 554. 
revolts abounds with examples of rebels convinced that the bullets of their enemies will turn into water as long as they are protected by magical charms and strictly obey certain rules and prescriptions. The best documented case is that of the 1964 Congolese rebellions. B. Verhaegen, ${ }^{21}$ more particularly, has extensively described how the Congolese rebels in Kwilu Province, under the leadership of Pierre Mulele, and even more so in the Eastern part of what is today Zaïre, repeatedly charged without fire-arms against the machine guns of the Congolese National Army, chanting their war-cry "Maie Mulele" or "Maie Lumumba" which, they believed, would protect them from any harm. In this case, magical beliefs gave rise to very elaborate rituals and codes of conduct, while the traditional "doctors" were incorporated within the rebels' army hierarchy, receiving regular pay. According to Verhaegen these "féticheurs" were highly respected by the insurgents ("L'absence de docteur était cruellement ressentie") and there was one doctor to every 10 to 15 ordinary soldiers. ${ }^{22}$

Similar beliefs in magical devices guaranteeing invulnerability and invincibility in combat have been reported in the case of the Malagasy rebellion, ${ }^{23}$ and in that of the 1961 Northern Angolan insurrection, but in the latter case only during the first months of the revolt. ${ }^{24}$ The liberation war in Zimbabwe in the 1970s also gave rise to similar phenomena, participants in the war maintaining that their ancestors guarded and advised them. ${ }^{25}$ In this case too, the guerillas believed that their spirit mediums' patent cure-all could protect them from the bullets of

21. B. Verhaegen, "Rébellions au Congo", Tome 1, Les Etudes du C.R.I.S.P., Bruxelles, 1967; B. Verhaegen, "Rébellions au Congo", Tome 2, Les Etudes du C.R.I.S.P., Bruxelles, 1969.

22. B. Verhaegen, Tome 2, pp. 561-562. It should be mentioned here that Pierre Mulele and at least some of his Kwilu followers, according to L. Martens, and contrary to what is claimed by Verheagen and others, did not themselves believe in magic (Cf. L.

Martens, "Pierre Mulele ou la seconde vie de Patrice Lumumba", Editions EPO,

Berchem (Anvers), 1985, pp. 230-232). I have to admit that I feel somewhat uneasy with Martens' affirmations as they are almost exclusively based on recent interviews with survivors from the Mulelist maquis: at this point in time, Mulele's partisans have a vested interest in denying magical beliefs which have given their rebellion a "bad", i.e. retrogade image.

23. J. Tronchon, op.cit., pp. 358-360.

24. R. Davezies, op. cit., p. 63; R. Pélissier, op. cit., p. 560.

25. D. Lan, Guns and Rain: "Guerrillas and Spirit Mediums in Zimbabwe", James Currey, London, 1985, p. XVIII. 
the enemy, ${ }^{26}$ but $\mathrm{D}$. Lan, who analyzed this case, hastens to add that "few if any of the guerrillas relied exclusively for their safety on magical precautions. Nor would the mediums have expected them to. Sound planning, courage and discipline were the recognised requirements of a successful military campaign (...). All the evidence suggests that guerrillas and peasants held two contrasting ideas in their heads at the same time. Ancestral protection and rigorous military discipline were both essential". ${ }^{27}$

As we have seen, the Congolese insurgents and their Northern Angolan counterparts were less cautious, and swallowed the magic hook and sinker. These examples, again, provide us with cases of rebels acting on the basis of erroneous information, or rather incorrect hypotheses. Ironically enough, though, magic sometimes works under African circumstances, at least in the short run. Surely, in most of the cases, African rebel groups charging against machine guns, believing they were invulnerable thanks to magical devices, incurred heavy losses and were decimated within a few minutes. But this was not always so. In the Congo, more particularly, the rebels' belief in their immunity was shared by many of their adversaries in the Congolese National Army who, on several occasions, panicked and fled without even engaging battle; in fact, sometimes the rebels not only attacked without firearms and without protection, but also after having duly informed their enemies of the day and the hour of their assault, a warning that ended the battle before it had started ${ }^{28}$ It took more hardened and less superstitious Congolese soldiers, and some European mercenaries who did not believe in magic at all, to stop the rebels and defeat them in a later stage of the war, but at least for a few weeks the rebels' magic did work. ${ }^{29}$ Another case where magic seems to have had some influence on the outcome of the encounters between insurgents and the security forces relates to the 1968-69 Agbekoya revolt in Ibadan, Western Nigeria:

"Force was by no means the farmers' only weapon. Police, army and citydwellers were even more afraid of their alleged powers of magic. Ju-ju sprinkled around the council offices and police stations was a potent means

26. Ibid., p. 158.

27. Ibid., p. 209.

28. B. Verhaegen, Tome 1, p. 481.

29. Note that the Congolese simba (rebels) were themselves convinced that some of their grass-roots opponents (not the Congolese National Army) disposed of magical powers superior to theirs. The simba never ventured into Songye country, one of the reasons being that this ethnic group commanded exceptionnally strong magical powers that were widely feared by all their neighbours. 
of preventing the actions of officialdom in the early period (...). Many stories were told by terrified policemen and soldiers of, for example, 'the ground rising and falling in waves' when patrols were ambushed, and of men being deformed or injured without being touched by bullets or machetes ". ${ }^{30}$

And yet, in spite of some ephemeral successes, the Agbekoya rebels, too, lost their war. Magic, in the end, was no short-cut to victory.

The question that arises when considering the examples of African revolts quoted above, and especially those where magical beliefs played a role, is whether these rebels still behaved in a rational manner. This depends, of course, on how one defines rational behaviour. J.B. Rule uses the following definition of rational action: "That in which ends, timing, tactics and the like are as though selected in terms of efficiency calculation, so as to serve enduring interests of the participants or others represented in the action. Thus militant collective action appears rational insofar as its form, timing and targets minimize costs or maximize payoffs in relation to goals or interests apparent in participants' actions in other settings". ${ }^{31}$

Although the Congolese $\operatorname{sim} b a$ rebels undoubtedly made some crude efficiency calculations, I wonder whether their behaviour would qualify as rational in this definition. R. Aya, on the other hand, uses a definition that is somewhat more extensive and that leaves sufficient loopholes for the Congolese guerrillas to qualify:

"To call an action 'rational' is to say the actor expects it to gain his goal (...). The guts of a rational-choice explanation are what the actors want and think they must do to get it not one's own evaluation of their goals or credence in their ideas about what they can do and what will be consequent to alternative courses of action". ${ }^{32}$

According to this argument, magic would be rational if people really believed in it, which was certainly the case in the Congo. However, Aya himself seems to feel a little uneasy with his statements when he introduces the caveat that rationalchoice theory explains sane people's premeditated social actions, not the behaviour of infants, idiots, psychopaths, and people who are senile, hallucinated, panicked

30. C.E.E. Beer, "The Politics of Peasant Groups in Western Nigeria", Ibadan University Press, Ibadan, 1976, pp. 194-195.

31. J.B. Rule, "Rationality and Non-Rationality", p. 145.

32. R. Aya, "Rethinking Revolutions", pp. 103-104. 
or brain-damaged. ${ }^{33}$ At first this seems quite logical, but on second thought the question rises whether the Congolese simba were "sane" people who expected to gain their goals by magical devices, or "hallucinated" lunatics no longer in touch with reality. Note that the simba not only believed in magic, but regularly consumed hemp, especially before combat. ${ }^{34}$ Other African rebels have been reported to do the same and one may therefore consider the hypothesis that at least some African insurgents were hallucinated people beyond the realm of rational thinking, a hypothesis not foreseen in Aya's argument. Aya's caveat, in a way, undermines his own theory.

I do admit, however, that rationality, as Aya suggests, should not automatically be defined as "Western" rationality. Other types of rationality do indeed exist, including those based on magic, and one can certainly not deny African insurgents the virtue of efficiency calculations. However, and this is an important point when elaborating general theories on civil violence, non-Western types of rationality can only work as long as they are applied in their autochthonous context. A rebellion, especially in our times, unfortunately enough for the insurgents, has to tackle enemies who use Western rationality, i.e. calculations based on fire-power, military tactics and strategy, communications, etc. Rebels can only win if they use the same type of rationality; if not, they remain within the realm of what G. Althabe called "la libération dans l'imaginaire". ${ }^{35}$ This does not invalidate Tilly's and Aya's hypotheses on the rational rebel, but it should urge us to pay more attention to the question of the extent to which rational action is effectively linked to reality, when we wish to evaluate the chances rebels have to "get away with it".

This brings me to another question: do all rebels really think that they have a fair chance to attain their goals, as "rational rebel" theory seems to imply? In fact, I am not so sure of this. One thing has always puzzled me: we know from history that most rebellions fail, and yet, time and again, people revolt. Do they really think they can attain their goals, win the war, in spite of "the lessons of history"? In most cases yes, although they often seem to have all the odds against them, seen from the point of view of a neutral or even sympathetic outsider. I still wonder, for example, whether Amilcar Cabral, in the early 1960s, really believed he could win the liberation war against the Portuguese in Guiné-Bissau,

33. Ibid, p. 104.

34. B. Verhaegen, Tome 2, p. 594.

35. G. Althabe, "Oppression et libération dans l'imaginaire. Les communautés villageoises de la côte orientale de Madagascar", François Maspéro, Paris, 1969. 
but we will probably never get a sure answer to this question. In other cases, however, people revolt knowing that they will lose. We are all familiar with the "rather die a free man, than live as a slave" and similar lines of thinking, and although I have no case in my sample of African rebellions of whole groups of people acting in this spirit, there is at least one African revolutionary leader who seems to have become involved in a revolt he knew would probably end in failure.

I am referring here to the Cameroonian UPC leader Um Nyobé of whom it is known, first of all, that he did not approve the May 1955 riots instigated in Douala and other towns by some of his closest lieutenants, because he thought that violent action, at that point in time, was premature since the UPC organization was not ready for a fully-fledged guerrilla campaign. ${ }^{36}$ Yet, Um Nyobé, faithful to his UPC engagement, took refuge in the rural Bassa areas once the riots had started, in order to mobilize his people and to prepare, if not for war, at least for resistance. Again, when violence occurred on a larger scale in Bassa country in December 1956, nobody thought that Um was the real instigator of the troubles: "Il a été, dit-on, dépassé par des 'excités'". ${ }^{37}$ Later on, in August 1958, when the French had imposed full-scale warfare on his Sanaga-Maritime maquis, Um managed to pay a clandestine visit to Douala to consult with his political friends on the question whether or not to try to "return to legality". According to G. Chaffard, Um himself was in favour of such a course of action, but the majority of his associates voted against it. Again, faithful to his engagement, Um returned to his hiding-place in the forest where he was killed by French troops only a month later. ${ }^{38}$

Um Nyobé, the reluctant rebel, "le maquisard malgré lui"? His own writings, and especially those he published sous maquis, basically confirm Chaffard's interpretation of the events, an interpretation that is also shared by J.A. Mbembe who published these texts. ${ }^{39}$ None of them are based on the theme "we are going to win the war", as is customary in most of the triumphalistic revolutionary literature I am familiar with, and in one of his manifestos, dated January 3th, 1957, Um claims that since 1955 the UPC "n'a cessé de multiplier les efforts pour parvenir

36. G. Chaffard, op. cit., p. 365 .

37. Ibid., p. 369.

38. Ibid., pp. 382-385.

39. Cf. J.A. Mbembe, "Introduction" in: R. Um Nyobé, "Ecrits sous maquis", L'Harmattan, Paris, 1989. 
à un réglement pacifique du problème kamerunais", defining the action of his people as "passive resistance". ${ }^{40}$

This does not imply that Um Nyobé refrained from making rational calculations, quite the contrary, but it indicates that not all rebels, even "rational" ones, are convinced they can get away with it. Um consciously accepted the leadership of the UPC revolt, not because he thought he could win the war, but in order to remain faithful to his convictions. There are certainly more cases of such reluctant rebels in history, and although the rationality of their actions is not in doubt, they do not fit into the "rational rebel" theories as formulated by Tilly, Aya and others. Their hypotheses, therefore, need to be refined in order to accommodate the case of the reluctant rebel. ${ }^{41}$

\section{How rebellious?}

\section{Rebels out of necessity}

Here I will consider cases of social actors who consciously take the decision to revolt, but whose motives are not necessarily "revolutionary". First of all, we will look at the behaviour of people who join a rebellion for "negative" reasons, i.e. not so much for the collective or individual rewards they expect to obtain from this choice, but in order to avoid anticipated suffering and/or punishment.

In order to introduce this subject, I will first refer to the thesis of $\mathrm{Ch}$. Tilly who claims that the genesis of collective violence should not be analyzed exclusively from the actions of the insurgents, but also from the repressive and sometimes

40. Cf. R. Um Nyobé, op. cit., p. 187 and p. 190.

41. Note that there are also examples of political leaders consciously deciding not to take part in a revolt they initially helped to prepare. This has probably been the case with some Kenyan trade-union leaders who, from 1950 till October 1952, directed the oathing campaigns in Nairobi and the Kikuyu areas that led to the Mau Mau revolt. One of them, Bildad Kaggia, confirms in his Memoirs that he was informed together with some of his associates about his imminent arrest 24 hours before the October 20 Emergency Declaration; yet he quietly waited for the Security Forces to take him to jail. He was probably well aware that the Emergency Declaration came too soon, i.e. at a moment the organization he led was not yet ready for sustained guerrilla action and was bound to lose the war. Cf. R. Buijtenhuijs, "Essays on Mau Mau: Contributions to Mau Mau Historiography", African Studies Centre, Leiden, 1982, pp. 76-78. 
pre-emptive measures of the incumbents. As Tilly says: "Collective violence is a contingent outcome of interaction among contenders and governments, in which the agents of government commonly have the greater discretion and do most of the injury and damage". ${ }^{42}$ As for the specific case of Kenya, for example, B.J. Berman comes to the conclusion that the declaration of the Emergency, which in a sense marked the beginning of the Mau Mau revolt, was "a pre-emptive attack carried out by the incumbent colonial authorities against a significant segment of the African political leadership of Kenya and its supporters". ${ }^{43}$ The Mau Mau revolt thus "went off at half clock" and was "forced into the open" by the declaration of the Emergency. ${ }^{44}$ This, in turn, affected the recruitment of the Mau Mau fighters during the first stages of the rebellion, as is argued by D.L. Barnett:

"A significant sector of the European settler community tended to interpret the Emergency declaration and legislation as promulgating a sort of 'open season' on Kikuyu, Embu and Meru tribesmen: Forced confessions, beatings, robbery of stock, food and clothing, brutalities of various sorts and outright killings were frequent enough occurrences to arouse a fear in the hearts of most Kikuyu that the intent of the white men was to eliminate the whole Kikuyu tribe (..) this fear inaugurated a slow but steady drift of Kikuyu, Embu and Meru peasants, particularly the youth, into the forests of Mount Kenya and the Aberdares". ${ }^{45}$

As for the Kikuyu squatters on the White Highland farms, T. Kanogo comes to a conclusion that points in the same direction:

"Some of the squatter repatriates were driven to the forests as much through hunger as anything else. Most were landless and many lost what little stock they had owned through confiscation by European farmers or government

42. Ch. Tilly, quoted in B.J. Berman, "Bureaucracy and Incumbent Violence: Colonial Administration and the Origins of the 'Mau Mau' Emergency in Kenya", The British Journal of Political Science, April 1976, p. 146.

43. B.J. Berman, op.cit., p. 170.

44. L.S.B. Leakey, "Defeating Mau Mau", Methuen \& Co, London, 1954, p. 108. A more or less similar situation obtained in Cameroon where the May 1955 Douala riots that initiated the UPC insurrection were partly provoked by the colonial administration. Cf. R. Joseph, op. cit., p. 277.

45. D.L. Barnett and K. Njama, "Mau Mau From Within: Autobiography and Analysis of Kenya's Peasant Revolt", Monthly Review Press, New York and London, 1966, p. 71. 
personnel. Herded into hastily erected government transit camps, their only real choices were starvation, petty crime or life in the forest" ${ }^{46}$

This image of peasants fleeing government repression and forced repatriation was confirmed, ironically enough, by Dedan Kimathi, the most important Mau Mau military leader who stated in an "Open Letter to the British Authorities" in August 1953:

"Because of the Government's policy of moving people without any consideration, and of harassing them in the Reserves, many people have come to the forest for fear of being killed or badly beaten. As a result, Mau Mau has increased a thousand times and now I am glad that I have many soldiers". ${ }^{47}$

The Mau Mau revolt thus represents a clear case of a rebellion that during its first stage recruited a significant proportion of its members not because, or not only because of the revolutionary message it propagated, but because of the protection it was able to offer in its forest hide-outs. ${ }^{48}$

Other cases of ruthless government repression and overkill turning hesitant peasants into determined rebels are the 1947 Malagasy revolt, ${ }^{49}$ and the 1961 Northern Angolan insurrection. ${ }^{50}$ Examples of people joining a rebellion for such "negative" reasons as government reprisal or, more generally speaking, because they have no other choice, are not limited to insurrections in the first stage. Sometimes individuals make their decision to join the insurgents much later, when the revolt is already well on its way. Such was, for example, the case of N. Kabiro, an

46. T. Kanogo, "Squatters and the Roots of Mau Mau", 1905-63, James Currey, London, 1987, p. 139.

47. Quoted in Maina wa Kinyatti (ed.), "Kenya's Freedom Struggle: The Dedan Kimathi Papers", Zed Books, London and New Yersey, 1987, p. 57.

48. Special mention should be made here of Kikuyu women, some of whom "fled to the forest for no other reason than to run away from the harassment of the Home Guards", i.e. Mau Mau's Kikuyu opponents (Kanogo, op.cit., p. 146). See also L. Martens, op.cit., p. 195, who reveals similar motives for Pende women joining the $1964 \mathrm{Kwilu}$ revolt in the Congo.

49. Cf. O. Mannoni, Psychologie et colonisation, Editions du Seuil, Paris, 1950, p. 90, and $\mathrm{Cl}$. Bourdet, "Préface", in: P. Stibbe, "Justice pour les Malgaches", Editions du Seuil, 1954, p. 16.

50. R. Davezies, op. cit,. pp. 60-61, and R. Pélissier, op. cit., p. 553. 
"ordinary" Kikuyu, who noted in his Memoirs that at the beginning of 1954: "No one knew what the next day might bring or if he would be alive to see it. For my part, I decided that it was time I joined the Mau Mau fighting forces; life outside was becoming very hard to bear". ${ }^{51}$ Another example is Miss Esther Ngo Manguelle who, when asked why she had joined Um Nyobe's UPC maquis, replied: "Mais il faut savoir camerade qu'ici chez nous il fallait fuire quand on était upéciste ou sympathisant (...). Les valets faisaient payer à certains camerades qui ne voulaient pas prendre le maquis 10.000 francs ou 1000 chèvres. Quant à moi, ne pouvant pas trouver une pareille richesse j'ai opté pour le maquis". ${ }^{52}$ Again, when in 1976-77 the central highlands of Angola became the target of a vigorous repression campaign by the MPLA government, the almost inevitable effect was to drive many who might have remained neutral or become supporters of the new government right into the arms of J. Savimbi's Unita. This was more particularly the case of the Protestant élite who bore the brunt of the repression. ${ }^{53}$

These examples of groups of people or of individuals who, according to outside observers and their own testimony, join a rebellion because they have no other choice, lead me first of all to voice some critical remarks concerning E.R. Wolf's hypotheses on the revolutionary potential of different categories of peasants. One of Wolf's conclusions is in fact that the "most readily mobilized" peasants (not necessarily the most "revolutionary" ones) are the "middle" peasants, the independent small-holders who own the land they cultivate themselves, because, more than other categories of peasants, they have some tactical mobility and "tactical freedom".$^{54}$ The cases I have discussed above do not allow me to reject Wolf's thesis out of hand, but they do demonstrate that the tactical powers of at least some peasants who became rebels were, in fact, rather limited. In situations where the incumbent government is the agent first opting for violent action, neither middle nor other peasants have much tactical power left, and their joining a revolutionary movement does not necessarily demonstrate the intrinsic revolutionary potential

51. N. Kabiro, Man in the Middle, L.S.M. Press, Richmond, B.C., 1973, p. 61.

52. R. Um Nyobé, "Le problème national kamerunais", Editions L'Harmattan, Paris, 1984 (Présentation et notes par J.A. Mbembe), p. 418.

53. L.M. Heywood, "Unita and Ethnic Nationalism in Angola", Journal of Modern African Studies, 27 (1), March 1989, pp. 58-59. See also F. Bridgland, "Jonas Savimbi: A Key to Africa", Mainstream Publishing Company, Edinburgh, 1986, p. 31.

54. E.R. Wolf, "Peasant Wars of the Twentieth Century", Faber and Faber, 1973, pp. 290-293. 
of the category to which they belong. ${ }^{55}$ Of course, one should keep in mind that some of these "forced" rebels may already have had some revolutionary leanings: N. Kabiro could also have joined the Kikuyu Home Guard, after all, instead of opting for Mau Mau, while Miss Manguelle was harassed into rebellion because she was already a UPC sympathizer, but their tactical powers still appear rather restricted. Wolf's thesis, therefore, needs refinement, and should try to come to terms with the cases of rebels out of necessity, cases which, I suspect, are quite frequent.

Another point I want to bring up here concerns the claims of some theorists who emphasize the individual rationality of prospective rebels instead of the collective rationality of insurgent groups (Ch. Tilly being the best example of the latter category). Following M. Olson (The Logic of Collective Action (1965)), such authors as J.S. Migdal and S.L. Popkin argue that any attempt to organize for group action, and particularly group insurgency, must provide individual incentives, i.e. positive rewards to overcome resistance to collective action, especially in peasant communities. ${ }^{56}$ I agree that positive rewards and incentives do play a role in many cases, and we will see examples of this in the next section of this article, but on the basis of the data discussed above I tend to think that Migdal and Popkin overemphasize the necessity of positive rewards and underestimate negative motives based on the desire to escape repression and suffering. True, seeking protection from government oppression does in a way belong to the category of selective incentives and such motives do not refute the general hypotheses discussed here, but they are rarely mentioned in the literature, in spite of the fact that they are often quite important in determining people's behaviour.

\section{Rebellion as a career}

I will now turn to examples of rebels joining an insurrection for more positive (although, again, individual and even egoistic) reasons, i.e. the hope that their option for rebellion will result in positive rewards and gratifications. Let us first discuss the case of revolutionary leaders. Pointing to the antinomy between Marx

55. Cf. R. Buijtenhuijs, "The Revolutionary Potential of African Peasantries: Some Tentative Remarks", African Studies Centre, Leiden, 1991, Working Paper vol. 14.

56. S.L. Popkin, "The Rational Peasant: The Political Economy of Rural Society in Vietnam, University of California Press", Berkeley-Los Angeles-London, 1979, p. 252. Also J.S. Migdal, "Peasants, Politics and Revolution: Pressures toward Political and Social Change in the Third World", Princeton University Press, Princeton, 1974. 
and Pareto over the question of the personnel involved in violent action and referring to the latter's hypothesis that for insurgent elites "the quest for power is an end in itself", J.B. Rule asks the following question about the German Nazi Movement: "(..) are its goals and strategies, especially the violent ones, better understood as direct expressions of grass-roots interests, or as efforts by a cohesive group of determined activists to pursue power for its own sake?"157 Elsewhere in his book a similar question comes up: "But did the Bolsheviks of 1917 more closely resemble Marx's class-conscious representatives of down-trodden grass-roots insurgents, or Pareto's power-hungry insurgent elites?"58

These questions introduce us to the theme of "rebellion as a career". There is no reason to doubt that for many revolutionary leaders insurgency is partly or even mainly motivated by the possibility of upward mobility in situations where other paths of such mobility are blocked ${ }^{59}$ As for African leaders, I think that for men such as Amilcar Cabral or Samora Machel, upward mobility and political power was not their main concern when launching the war of liberation in their respective countries, but I have some doubts, for example, about certain Chadian Frolinat leaders such as Abba Sidick and Hissein Habré (not to mention Liberia's Charles Taylor and Prince Johnson). As for the Chadian Frolinat, I have argued elsewhere that most of the early and also some of the subsequent leadership of the movement was provided by a specific group of Arab-speaking young intellectuals who had studied in Cairo or Khartoum and whose diplomas (if they had obtained any) did not qualify them for public office in "French-speaking" Chad. For this frustrated "counter-élite", the Frolinat rebellion, campaigning amongst other things for the adoption of Arabic as Chad's second official language, indeed offered the prospects of a later career, and it seems rather probable that at least some of its members joined the movement mainly for this reason. ${ }^{60}$

Such positive rewards, now or in the future, not only motivate leaders but also grass-roots rebels in some cases. The Frolinat is again a good example. P. Doornbos convincingly argues that in 1977-78, when branches of the "revolutionary" movement controlled huge areas in Eastern Chad, rebellion became the only possible

57. J.B. Rule, "Theories of Civil Violence", p. 195.

58. Ibid., p. 252.

59. J.S. Migdal, op. cit., pp. 242-243.

60. R. Buijtenhuijs, "Le Frolinat et les révoltes populaires du Tchad", 1965-1976, Mouton, The Hague-Paris-New York, 1978, p. 119. Mixed motives may play a role in such cases. R. Aya rightly suggested to me that people often seek power because without it they cannot achieve their other goals. 
career for many young combatants. One of his informants, a trader born in Chad but living in Beida (Sudan), said:

"Ici, tu sais déjà compter, quand tu n'es qu'un gosse, avant d'aller à l'école. Si tu échoues á l'école ou si tu n'as plus envie, si tu veux gagner de l'argent, tu peux devenir berger, travailler sur le marché ou dans le commerce. Sinon, tu continue jusqu'à ce que tu rates un examen; alors tu trouves un poste dans l'administration comme commis ou comme instituteur...Mais là-bas (au Tchad), à quinze ans, tu n'as rien, tu ne sais rien, tu ne sais rien faire. Là-bas, il n'y a pas d'école, pas de commerce, pas d'hukùma (government) (...) Là-bas, un garçon n'a que deux choix: partir au Soudan ou devenir suwaari (rebel)". ${ }^{61}$

Living from the "contributions" of the local peasants, mostly obtained at gun-point, contrary to the practices that obtained during the earlier phases of the revolt when peasants shared the rebels' ideals and supported them voluntarily, these Frolinat suwaar did nothing but making a career, and most of them, albeit certainly not all, were not driven by any revolutionary leanings. The Chadian example is a particularly dramatic one, but others can be quoted too. B. Verhaegen, for example, claims that when the Congolese simba conquered the Eastern town of Kosongo and started recruiting local fighters their main source of recruitment were those called "les chômeurs", in fact young men between 12 and 20 years old who had been forced to abandon their schooling and were then left without further prospects: "Aux jeunes déscolarisés s'ajoutaient de vrais chômeurs (...). L'engagement dans l'Armée populaire signifiait pour eux (...) un gagne-pain immédiat et une revanche sur la fraction sociale à laquelle ils attribuaient leur déchéance et leur misère" ${ }^{62}$ Mozambique's South African sponsored Renamo movement, in its turn, benefitted from the general economic recession following independence that left many young men in the rural areas without any prospects of a normal career. Ch. Geffray, who studied the Renamo movement in Erati district, certainly does not claim that any of these young men joined Renamo for these reasons (many of them were in fact kidnapped), but he does hold that quite a few of them remained with Renamo because being a Renamo soldier offered them an escape from the boredom and inactivity of their rural life and represented for them "a flashing promotion when compared to their social condition in their native environment". ${ }^{63}$

61. P. Doornbos, "La révolution dérapée: La violence dans l'Est du Tchad (1978-1981)", Politique africaine, No. 7, September 1982, pp. 7-8.

62. B. Verhaegen, Tome 2, p. 312.

63. Ch. Geffray, "La cause des armes au Mozambique: Anthropologie d'une guerre civile", CREDU-Karthala, Paris, 1990, p. 111. 
The cases quoted above relate to rational social actors consciously joining (or remaining with) an insurgent movement and they correspond to the Migdal-Popkin model of the rational rebel. The only point is that these people are not really "rebels" in the strict sense, a feature that appears to me as important enough to pay some attention to - more at least than some of the theorists of civil violence do.

Note also that some revolutionary leaders, and more particularly African ones, were themselves aware that material rewards and benefits are an important incentive for people to support an insurgent movement. Amilcar Cabral, for example, in a confidential memorandum written in 1965, instructed his fellow PAIGC members to "Keep always in mind that the people are not fighting for ideas, for the things in anyone's head. They are fighting .. for material benefits, to live better and in peace, to see their lives go forward, to guarantee the future of their children. National liberation, war on colonialism, building of peace and progress independence - all that will remain meaningless for the people unless it brings a real improvement in conditions of life" ${ }^{64}$ Words echoed by those of ZIPRA political commissar Colin Matutu, who said about his mobilizing tasks in the rural areas of Zimbabwe: "We didn't only talk political theory, for people did not understand all that political jargon (...). You dont talk about the capitalist or the socialist state to them. What mattered to them was how to do away with their grievances at the present time". ${ }^{65}$

Note also that people do not only, or exclusively, join insurgent movements in order to obtain material rewards. As Rule says: "Perhaps, for some forms of action, the long-term, strategic consequences matter rather little to participants, compared to the inherent satisfactions of acting. Perhaps, in other words, the strictly consummatory rewards of inflicting pain on one's enemies or of destroying a hated symbol suffice to motivate violent action". ${ }^{66}$ Lust for adventure, the exaltation of engaging in armed combat are other consumatory rewards people may seek to obtain through enlistment in the ranks of an insurgent movement. According to $\mathrm{Ch}$. Geffray, such motives play an important part in the decision

64. Quoted in B. Davidson, "The Liberation of Guiné: Aspects of an African Revolution", Penguin Books, Hammondsworth, 1969, p. 122.

65. J. Frederikse, "None but Ourselves: Masses vs Media in the Making of Zimbabwe", Heinemann, London-Ibadan-Nairobi, 1982, pp. 60-61.

66. J.B. Rule, "Theories of Civil Violence", p. 190. 
of young Mozambican peasants to remain with Renamo, ${ }^{67}$ and there are certainly other cases where people opt for rebellion at least partly for such consummatory ends.

There are also other reasons why men (or women) may become rebels without being revolutionaries. As for a revolt that occurred in Santo Domingo, in 1965, H.A. Landsberger, quoting Moreno, claims that "even among the 4,000 activists, ideology had little to do with participation (...). What seemed to have occurred most frequently in Santo Domingo was that a pre-existing informal group followed its informal leader. If he felt (...) that the revolution should be supported, they would become part of the rebel para-military force. If not, they would not participate" ${ }^{68}$ The same can happen in the case of more formal groups. According to official documents, during the first months of the Frolinat rebellion in Northern Chad, several cantons turned to the rebellion en bloc, following the call of their chefs de canton. ${ }^{69}$

In other cases people may become rebels in order to pursue (individual or collective) sectoral aims that are not necessarily revolutionary by nature, or that are revolutionary in a way that differs from the goals defined by the movement they adhere to. This is more particularly the case with women. N. Kriger, for example, analyzes how during the liberation war in Zimbabwe, rural Shona women, without becoming combatants themselves, sought to establish close relations with the guerrillas in order to further their own interests as (married) women: "Women's articulated demands were for their husbands to stop beating them and cease drinking (...). From all accounts, the guerrillas then punished the husbands by beating them (...). For a brief period, wives acquired control over their husbands". ${ }^{70}$ We have here a quite obvious case of women trying to use a liberation movement in order to protest against male control, an attempt that failed in the end because later on the guerrillas were persuaded by the men in the villages to put an end to their allegiance to women and to refrain from interfering in people's private

67. Ch. Geffray, op. cit., p. 111-112.

68. H.A. Landsberger, "The Problem of Peasant Wars", Comparative Studies in Society and History, 15 (3), June 1973, p. 385.

69. R. Buijtenhuijs, "Le Frolinat", p. 109.

70. N. Kriger, "Popular Struggles in Zimbabwe's War of National Liberation", Paper read at the Canadian African Studies Association Annual Conference, Kingston, Ontario, May 11-14, 1988, p. 13. 
lives (and also because the guerrillas themselves were often quite traditional "male - chauvinist" - in their attitudes towards women). ${ }^{71}$

Young women, in Guiné-Bissau, wishing to further gender-related interests, not only sought close relations with the PAIGC fighters, but effectively joined the party as combatants, in an attempt to escape oppressive customs such as forced marriage, lack of divorce rights for women, and polygyny. ${ }^{72}$ In this case, the liberation movement itself was "equally insistent that all discriminatory practices, including those affecting women, be discouraged and in time discontinued", and, according to S. Urdang, forced marriage had virtually disappeared in the liberated zones by the end of the war. ${ }^{73}$ In Mozambique, too, young women are reported to have enrolled in Frelimo in order to escape male dominance, ${ }^{74}$ and in this case, too, the liberation movement espoused their cause, although it turned out, after independence, that this was partly a question of opportunism and paying lip-service. ${ }^{75}$

Young men also sometimes indulge in revolutionary action partly for reasons of their own, as for example in Zimbabwe: "The closer contacts between youth and guerrillas gave youth a considerable leverage over parents, and especially in areas where the guerrillas frequently visited, children were no longer so dependent on their families for food and shelter as they ate and slept with the guerrillas (...) youths' challenge to their parents was summed up in their assertive claim: 'We are not your sons. We are the sons of Zimbabwe'" ${ }^{76} \mathrm{~A}$ long list can be compiled of other African rebellions were phenomena similar to those obtaining in Zimbabwe also occurred.

In such cases, people joining a rebellion, again, are not necessarily moved by revolutionary ideals, although sometimes their motives can be in a way more

71. Ibid., p. 14.

72. S. Urdang, "Fighting Two Colonialisms: Women in Guinea-Bissau", Monthly Review Press, New York and London, 1979, p. 141.

73. Ibid., p. 150 and p. 156.

74. M. Manceaux, "Les femmes du Mozambique", Mercure de France, s.1., 1975, p. 143.

75. Cf. S. Arnfred, "Women in Mozambique: Gender Struggle and Gender Politics", Review of African Political Economy, No. 41, 1988.

76. N. Kriger, op.cit., p. 3 and p. 6. 
revolutionary than the aims of the movement they adhere to. N. Kriger is quite right when she argues that the competing interests that tried to use ZANU's guerrilla organization as a political resource often made more revolutionary demands than the guerrilla organization did $^{77}$; had ZANU, for example, been concerned with social change, it would have attacked the lineage organization of Shona society that is at the heart of gender and generational relations, but this "was never part of the nationalist agenda". ${ }^{78}$ Women and youth, therefore, were more "rebellious" than the liberation movement, but on their own lines.

At last, a few remarks are appropriate about "rebels" who are neither rational, nor rebellious at the outset. I refer here to people kidnapped by insurgent movements and forced to fight or to attend to the needs of those who fight. As for kidnapped males, Renamo is the most obvious example. According to W. Minter who, towards the end of 1988, interviewed 33 ex-Renamo fighters, forced recruitment was overwhelmingly dominant in his sample, and the pattern revealed in his interviews is fully consistent with numerous other sources: according to Minter, probably at least $90 \%$ of the Renamo rank-and-file are recruited by force. ${ }^{79}$ Although $\mathrm{Ch}$. Geffray puts the proportion of kidnapped Renamo fighters less high, he, too, reports the same practices. ${ }^{80}$

Renamo is also known for its widespread practice of kidnapping women, not to use them as fighters, but as "wives" for its officers and trusted soldiers. ${ }^{81}$ Interestingly enough, Frelimo, Renamo's Mozambican "predecessor" in rebellion, is also reported to have occasionally abducted women, ${ }^{82}$ and the same is the case with the Congolese rebellions, ${ }^{83}$ and the Mau Mau revolt. ${ }^{84}$

77. Ibid., p. 2

78. Ibid., p. 21.

79. W. Minter, "The Mozambican National Resistance (Renamo) as described by Exparticipants", Facts and Reports, Index 1988, 18th Volume, pp. 2-3.

80. Cf. Ch. Geffray, op. cit.

81. Ibid., p. 96.

82. M. Manceaux, op. cit., p. 199.

83. B. Verhaegen, Tome 2, pp. 577-578, and L. Martens, op. cit., pp. 27-28. The last author relates how Léonie Abo, later to become one of the main women leaders of the Kwilu maquis and the wife of Pierre Mulele, was tricked into his hide-out and forced to stay there as a nurse, at first against her will. 
The foregoing considerations about rational, but not necessarily revolutionary rebels demonstrate that individual motives for participating in collective violence vary widely and that, as is suggested by Rule, we should "question any assumption that 'the same sort' of phenomena must necessarily share the same origins (...). The fact that participants in (...) events appear to be doing 'the same thing', for example, gives no assurance that the same forces underlie the behaviour of everyone involved" ${ }^{85}$ People may indeed participate in civil violence for reasons as widely divergent as high ideals, solidarity with members of one's own group, obedience to a trusted leader, calculated self-interest, or consummatory motives such as lust for adventure, not to forget the case of forced rebels. Moreover, many social actors, if not all, normally have mixed motives, and can participate in violent action for idealistic reasons without forgetting, at the same time, at what side their bread is buttered. Also, people change in the course of time: the same Léonie Abo, who at first loathed Pierre Mulele, later on became one of his most convinced and enthusiastic followers. ${ }^{86}$ Some of the women kidnapped by Frelimo, too, changed heart afterwards; as one of them said: "I felt very soon that they (the Frelimo soldiers) (...) knew the suffering of the people and that I had found real friends" ${ }^{87}$ Remember also how some of Renamo's captive soldiers remain with the organization because it offers them a "career" and an outlet for their sense of adventure. In all these cases, rationality is involved, but it is not always the rationality put forward by the theorists of civil violence when they analyze the behaviour and motivations of rebels.

84. T. Kanogo, op. cit., p. 146.

85. J.B. Rule, "Rationality and Non-Rationality", p. 153.

86. Cf. L. Martens, op. cit.

87. M. Manceaux, op. cit., p. 199. 